\title{
Development Institutions and Their Role in Maintaining Financial and Innovative Infrastructure of the State
}

\author{
S.P. Sazonov, I.A. Ezangina, E.E. Kharlamova, I.A. Chekhovskaya* \\ Volgograd State Technical University, Volgograd, 400066, Russia \\ *Corresponding author.Email: chehovskaia_irina@mail.ru
}

\begin{abstract}
Development institutions are one of the instruments of state policy that stimulate innovation processes and development of institutional infrastructure using public-private partnership mechanisms. This article discusses the concept, essence and classification of development institutions, defines their role in maintaining financial and innovative infrastructure of the state.
\end{abstract}

Keywords: development institutions, infrastructure, innovations, investments, financial support, public-private

partnership, socio-economic development

Development institutions occupy a special niche in the economy between the commercial sector and direct budget financing. The task of development institutions is to act as a catalyst for private investment in priority sectors of the economy and create conditions for the infrastructure that provides access to the necessary financial and information resources for enterprises operating in priority sectors of the economy. [1]

From the analysis of definitions of 'development institutions' given by various authors, it can be concluded that development institutions are specialized organizations created by the state, based on the mechanism of publicprivate partnership, the main purpose of which is implementation and co-financing of priority projects for the economy and society. [2]

Russian development institutions have come a long way. Today, there are quite a few federal and regional development institutions: 'Vnesheconombank', 'Russian Venture Company', 'RUSNANO', 'Fund for the Promotion of Small Forms of Enterprises in the Scientific and Technical Field', 'Rosinfokom' and others. [3]

Distinctive features of development institutions in comparison to other forms of state support are:

1) redistribution of resources in favor of development projects aimed at creating economic growth potential in the field of infrastructure, human potential, new technologies, and supporting new, not yet dominant sectors of the economy;

2) a permanent organizational structure and certain rules, which allow development institutions carry out systematic activities; they have a clear system of responsibility and control;

3) development institutions are non-profit organizations, and not a way to increase the state's share in the economy; their activity is aimed at developing private business in new sectors of the economy. [4]
There are some services that development institutions provide, as presented in Table 1.

The components of development institutions' infrastructure can be divided into six blocks (financial block, innovation block, consultation block, block of unions and associations, special zones of economic development, educational block), which are presented in Figure 1.

This division of development institutions clearly demonstrates the institutional scope of development institutions and what functions they perform, this classification will help determine which development institutions need to be created to improve a component of the financial and innovative infrastructure. $[7,8,9]$.

Over the past decade, Russia has managed to significantly improve its position in leading international ratings characterizing the conditions for economic growth (Global Competitiveness Index and Doing Business) and its quality (Global Innovation Index). The biggest breakthrough in both the long and the short term is noted in creating favorable conditions for doing business. Thus, in the 'Institutions' block, Russia has risen by 44 positions: from 117th place in 2010 to 73rd in 2017. Today, Russia's innovative development is rated by international experts at the level of countries such as Greece (44th place in the Global Innovation Index rating), Romania (42nd), Turkey (43rd) and Chile (46th). A gap with the leading innovative economies of the EU countries remains. Among the BRICS countries, Russia is inferior to China (22nd place).

Overall, positive dynamics of Russia's positions in authoritative international ratings is the achievement of a state policy to support innovations implemented in recent years. 
Table 1 Services provided by development institutions

\begin{tabular}{|c|c|c|}
\hline Development institutions & Service content & $\begin{array}{l}\text { Types of services } \\
\text { provided }\end{array}$ \\
\hline 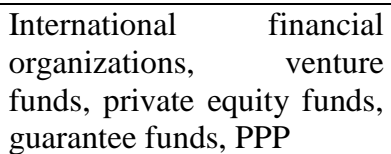 & $\begin{array}{l}\text { They attract investments in the form of PPPs, concessional lending to } \\
\text { priority sectors of the economy, investments in direct investment } \\
\text { funds, and provide loan guarantees }\end{array}$ & Financial \\
\hline $\begin{array}{l}\text { Councils, associations, } \\
\text { unions }\end{array}$ & $\begin{array}{l}\text { They coordinate business and state development strategies, are a } \\
\text { communication platform for exchanging views between interested } \\
\text { parties }\end{array}$ & Coordinating \\
\hline $\begin{array}{l}\text { Business incubators, } \\
\text { technology parks, industrial } \\
\text { parks }\end{array}$ & $\begin{array}{l}\text { They provide a wide range of services to a business located in a certain } \\
\text { territory. Such institutions can extract significant external effects from } \\
\text { the concentration of enterprises }\end{array}$ & $\begin{array}{l}\text { Business services, } \\
\text { infrastructure }\end{array}$ \\
\hline Export agencies & $\begin{array}{l}\text { Provide marketing, information, legal, technological support for } \\
\text { enterprises entering global markets }\end{array}$ & $\begin{array}{l}\text { Promotion of goods } \\
\text { in new markets }\end{array}$ \\
\hline Educational institutions & $\begin{array}{l}\text { Provide a variety of information (legal, market, financial) regarding } \\
\text { activities in new sectors of the economy. Provide training in new } \\
\text { business areas }\end{array}$ & $\begin{array}{l}\text { Information and } \\
\text { educational }\end{array}$ \\
\hline Economic research centers & $\begin{array}{l}\text { Provide analytical justification and expert evaluation of development } \\
\text { strategies }\end{array}$ & Expert and analytical \\
\hline
\end{tabular}

Source: based on materials [5]

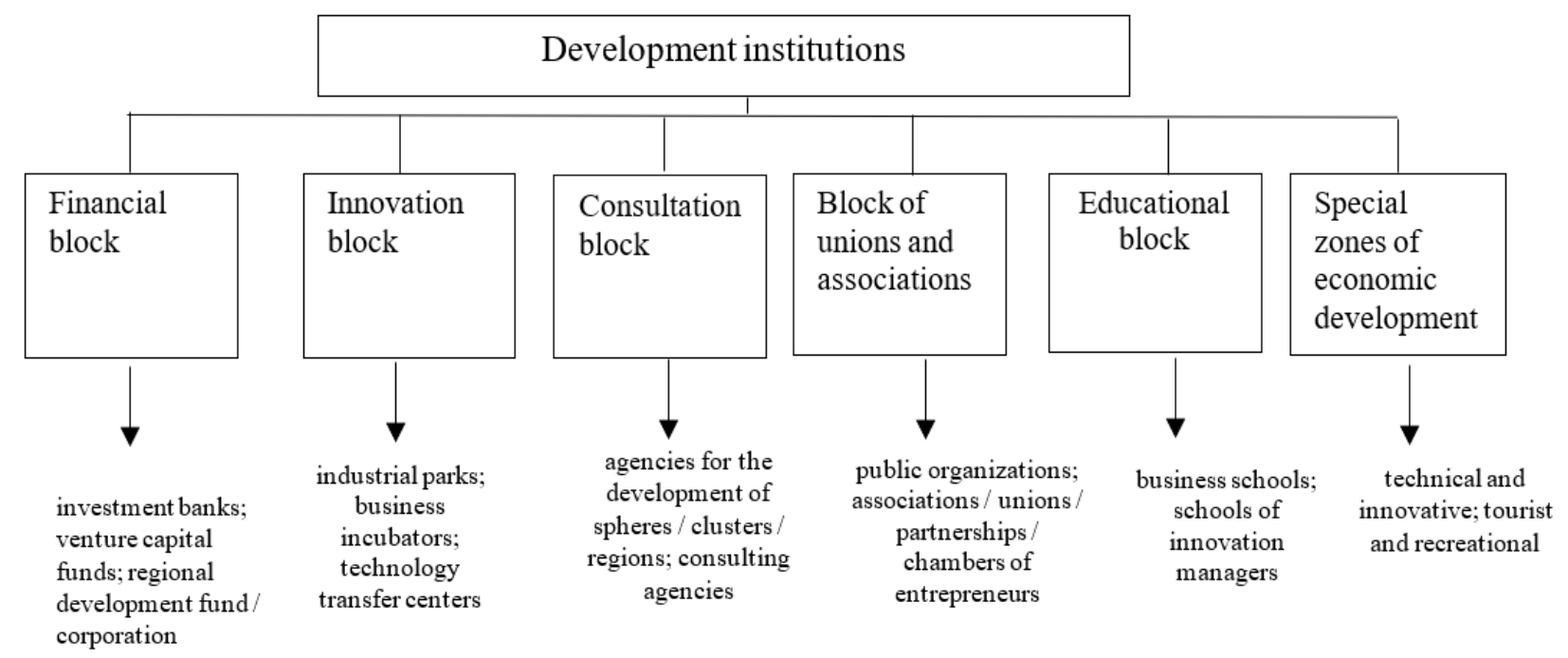

Figure 1 Types of development institutions Source: author, based on materials [6]

In this context, we are updating the role of the federal-level development institutions operating in the innovation sphere in Russia.

Projects' (ASI) was established on basis of the order of the Government of the Russian Federation dated August 11, 2011 No. 1393-p. The Agency was created to promote the development of social and professional mobility of young professional personnel and collectives in the field of medium business and social sphere by supporting socially significant projects and initiatives.

Thus, the Agency for Strategic Initiatives to Promote New Projects is called upon to promote innovative projects and initiatives of rapidly growing small and medium-sized businesses in the social sphere, to improve the entrepreneurial climate in the regions, to create a positive
Thus, the autonomous non-profit organization 'Agency for Strategic Initiatives for Promotion of New

image of the entrepreneur and entrepreneurship in general in Russian society, and also to promote formation and support of the renewed youth management. The Agency implements projects related to the creation of favorable conditions for doing business, attracting investments to the subjects and municipalities of the Russian Federation and improvement of efficiency of regional and municipal management teams.

The Russian venture company 'RVC' OJSC, is a stateowned fund of funds and a development institute of the Russian Federation, one of the key instruments of the state in building a national innovation system. 'RVC' OJSC was 
created in accordance with the order of the Government of the Russian Federation dated 07.06.2006 No. 838- p. $100 \%$ of the capital of 'RVC' belongs to the Russian Federation represented by the Federal Agency for State Property Management of the Russian Federation ('Rosimuschestvo').

The company's mission is to form a mature venture capital market and help Russia achieve technological leadership in priority areas through pooling and developing resources, competencies and initiatives of the state, society, private investors, entrepreneurs, research, expert and educational organizations to create and promote innovative products and technologies.

The company plays the role of the state venture capital fund through which state stimulation of venture investments and financial support for the high-tech sector are carried out, as well as the role of the state institution for the development of venture investment industry in the Russian Federation.

Since 2015, 'RVC' OJSC has been defined as a project office for the implementation of the National Technological Initiative (NTI), a long-term strategy for the country's technological development aimed at formation of new global markets by 2035 .

At present, 27 funds have been created with the participation of 'RVC' capital; the total volume of funds with the participation of ' $\mathrm{RVC}$ ' capital is 51.2 billion rubles. The amount of approved investments in 30 portfolio companies of funds in 2018 amounted to 2 billion rubles.

'RUSNANO' Limited Company was established on March 11, 2011 because of reorganization of the 'Russian Corporation of Nanotechnologies', founded in 2007. The company is a successor of the state corporation for all rights and obligations, $100 \%$ of its shares are in state ownership.

'RUSNANO' JSC implements the state policy for the development of nanotechnology industry, acting as a coinvestor in nanotechnology projects with significant economic or social potential.

'RUSNANO' Group is a basic development institution in the Russian Federation along with institutions for diversifying the economy, including the 'Skolkovo' Foundation, the 'VEB' Group, 'RVC' and others. 'RUSNANO' Group actively promotes the implementation of state economic policy by participating in the execution of state programs aimed at innovative development and modernization of the economy.

RUSNANO invests in innovative areas of medicine, electronics, renewable energy, which are important not only for the country, but also for every person.

'RUSNANO' JSC promotes implementation of the state policy on the development of nanotech industry by investing directly or through investment funds in high-tech projects creating new production facilities in Russia.

FSAI 'Fund of Industrial Development' (FID) was created to modernize Russian industry, organize new industries and ensure import substitution. The fund was created in 2014 on the initiative of the Ministry of Industry and Trade of the Russian Federation by transforming the Russian Fund for Technological Development, functioning since 1991. The fund offers preferential terms for co-financing projects aimed at developing high-tech products, technical re- equipment and creation of competitive industries based on the best available technologies. To date, the Fund has funded 502 projects worth 508.8 billion rubles.

Preferential borrowed co-financing is provided for projects aimed at import substitution, export and production of hightech civilian products.

It should be noted that projects supported by FID are significant both within a city, a region, and the whole country. Many projects are aimed at the development of import substitution, which is in demand in various product areas: in medicine, agriculture, resource extraction, consumer market, etc. Implementation of each project is accompanied by the creation of new jobs for residents of the country.

The mission of the Development Fund of the Center for the Development and Commercialization of New Technologies ('Skolkovo') is creation of the ecosystem, creation of favorable conditions for the innovation process: scientists, designers, engineers and businessmen, together with participants of educational projects will work on creation of competitive high-tech world-class developments in five priority areas: energy efficiency and energy conservation, nuclear technology, space technology and telecommunications, biomedical technology, strategic computer technology and software.

The expected result is a self-governing and self-developing ecosystem, favorable for the development of entrepreneurship and research, contributing to the creation of companies that are successful in the global market.

The Fund for Assistance of Small Forms of Enterprises in the Scientific and Technical Sphere implements programs aimed at creating new and developing existing high-tech companies, commercializing the results of scientific and technical activities, attracting investments in the sphere of small innovative entrepreneurship, and creating new jobs. The participation of startups in the Fund's programs allows to bring development from a scientific idea to creating a sustainable business that is attractive to domestic and foreign investors.

Thus, it can be stated that at present, development institutions at federal and regional levels are acquiring more and more importance in the system of innovation support. The relevance of this form of development institutions is associated with the need to develop scientific and technical potential for successful development in various areas of the country's economy and stimulate the innovative activity of domestic entrepreneurs in regions and municipalities.

Revealing the functionality of development institutions, we note that one of the most popular multi-instrumental forms of reproduction of real investments is project financing, which allows to accumulate significant financial resources from various sources on a long-term target basis, as well as to eliminate the risks of an investment project by redistributing them among participants permanently interacting throughout the entire period of the project. [10] It is important that the ideology of project financing is attractive to institutions of bank lending from the perspective of long-term profitability, the development of mechanisms for joint management of investment risks, diversification of activities, direct and indirect support of 
the state, the use of legally justified instruments of strategic, operational and current planning, especially financial and tax. $[11,12]$

Project financing involves provision of large loan products to customers with the goal of financing or refinancing investment projects in a wide variety of industries, including financing the acquisition of a 'ready-made business'. With the development of a project method of doing business in world practice, the need arose for introducing a fundamentally new mechanism for raising funds that allows you to carry out work without initially having any cash collateral. The main source of repayment is the cash flow generated during implementation of the investment project. In this regard, from the point of view of traditional lending such loan looks low-income and risky, possible only with the involvement of a wide range of participants sharing multiple risks.

Among the promising project finance tools, bank syndications, mezzanine and bridge financing are currently under consideration (Figure 2).

Mezzanine financing instruments include subordinated debt, preference shares, warrants, special coupon bonds
(PIKs - payment in kind). Mezzanine financing is used in cases of financing business growth, M\&A transactions, restructuring, repurchase of shares, project financing, lack of equity. $[14,15]$

For lenders, the benefits of syndicated lending are associated with distribution of credit risks among several lenders; diversification of the portfolio of an individual bank, increasing the liquidity of assets, expanding the circle of potential borrowers and customers, a positive reputation effect, simplifying debt management in the event of a default.

During its existence, more than $\$ 50$ billion has been mobilized from more than 500 financial institutions for more than 1000 projects in 110 emerging markets. The program participants are international commercial banks, local and regional banks, funds, insurance companies and development institutions (IFC, EBRD, KfW). Thus, in 2018 , the IFC syndicated loan portfolio amounted to $\$ 15.4$ billion (181 loans), including B-lending, parallel lending and portfolio management.

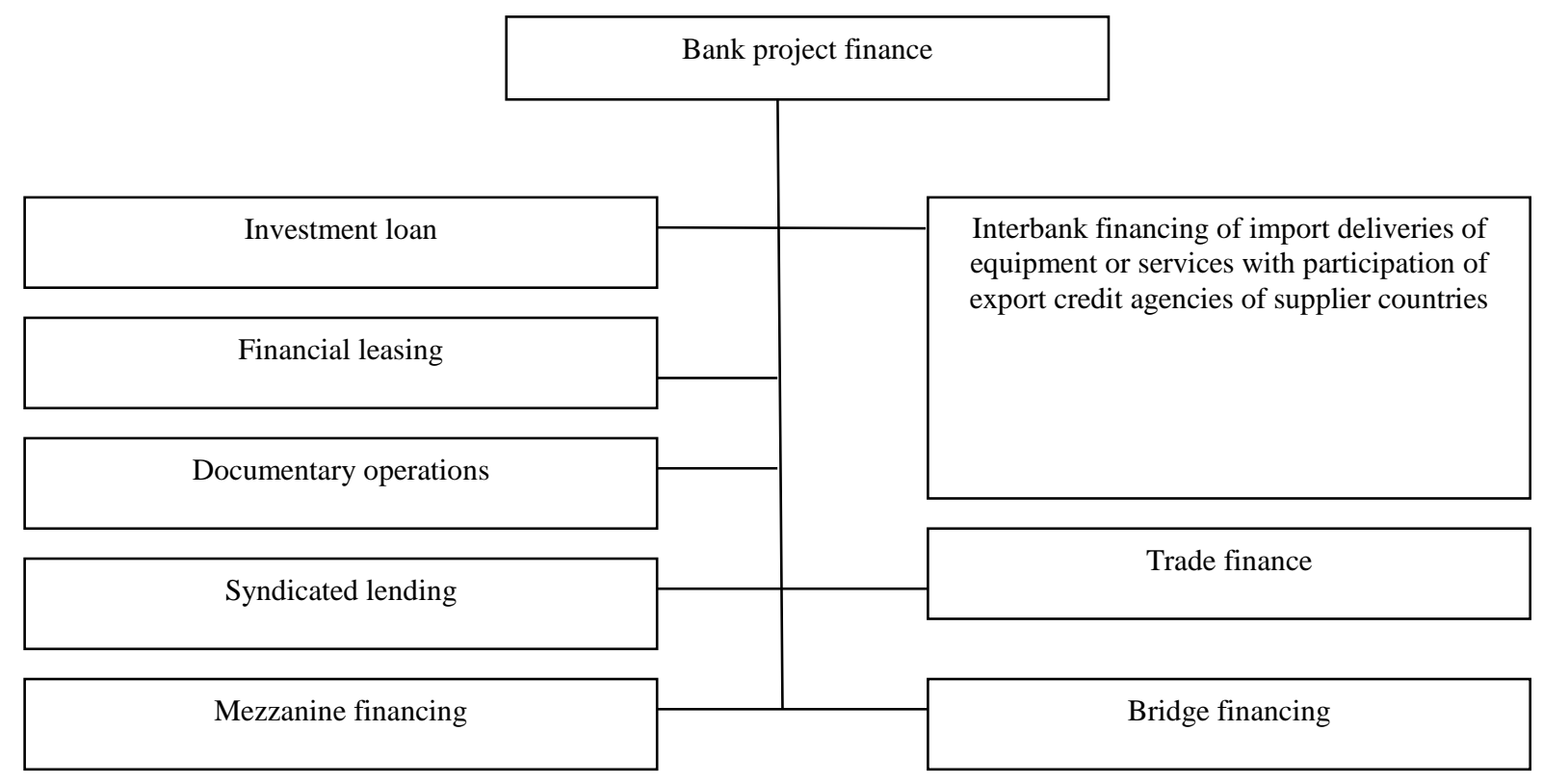

Figure 2 Type of bank loan products available under project financing Source: based on materials $[13,2]$

Development of the project finance market requires appropriate favorable conditions for the financial macroeconomic environment: developed legislation and legal regulation, availability of refinancing instruments (ECB, etc.), a constantly developing secondary market and availability of derivatives (credit risk insurance, etc.). Specific conditions of the Russian economy give rise to some features of project financing. Project financing is only possible for large banks and their consortia. Банк Интеза и Currently, system-forming banks having appropriate organizational units (Sberbank, VTB, Russian Agricultural
Bank, Gazprombank, Alfa-Bank, Uralsib, Intesa Bank, etc.) are engaged in project financing.

In this context, it is important to note the introduction by the Government of the Russian Federation a 2014 Decree No. 1044 on approval of the Support Program for investment projects implemented in the Russian Federation based on project financing and focusing on bank project financing. The document prescribes clear criteria under which a credit institution can become authorized to carry out an investment project based on project financing. The following are recognized as significant infrastructure assets: oil and gas 
guarantor, participant in investment lending. To contribute to the long-term economic development of Russia by supporting high-value industry and high-tech industry projects, supporting export and developing infrastructure that ensures economic growth - this is an official mission of the State Corporation 'Bank for Development and Foreign Economic Affairs' (Vnesheconombank, VEB, Bank), declared in the Strategy development until 2021 and the business model of VEB.

In 2018, VEB was endowed with new powers to organize and coordinate the activities of development institutions engaged in ensuring the long-term socio-economic development of Russia, in particular, the State Specialized Russian Export-Import Bank (Joint-Stock Company).

In order to expand the opportunities for VEB to participate in implementation of development projects, the Government of the Russian Federation decided to provide subsidies to the Bank in the amount of up to 600 billion rubles by 2024, an approach to additional capitalization of VEB in the amount of up to 300 billion rubles was determined using a new mechanism for Russian legislation - approved capital. Figure 3 shows the structure of VEB projects in areas in 2019. project financing requires an active position of development institutions, which should use their full potential as a

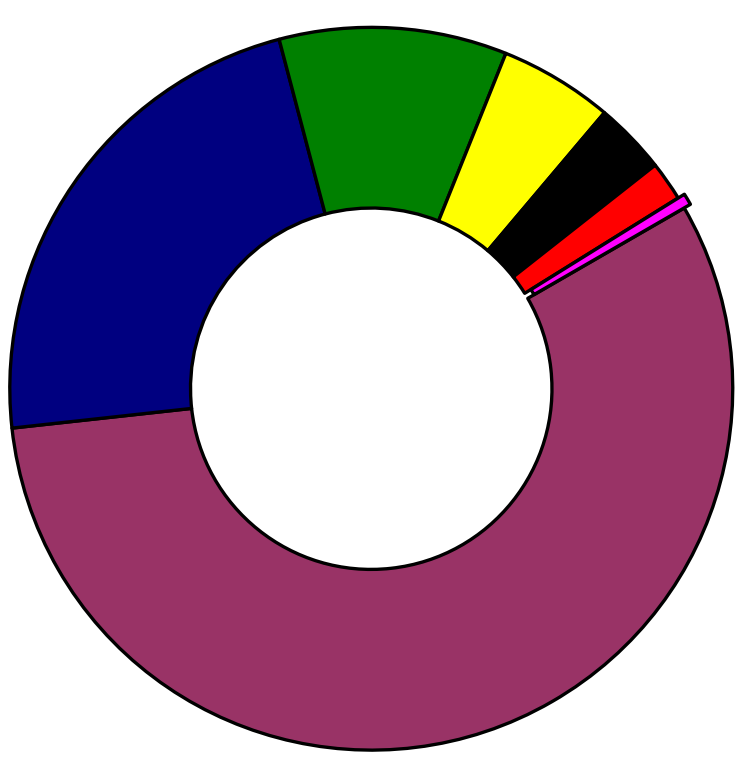

口Development of infrastructure

Improving the effectiveness of natural resources

QNational projects

口Export support

Other

口Innovation development

口Increase in energy efficiency

Figure 3 The structure of VEB projects in areas in 2019,\%

Source: [2]

VEB's activities complement the work of commercial banks as part of investment activities, while VEB may enter projects with commercial banks on the principles of cofinancing.

VEB's most significant projects are presented in Table 2.

Thus, in the Development Strategy until 2021, VEB sees a possibility of attracting syndication from commercial banks in its projects, working in two directions: creating syndicates and improving regulation of syndications. At present, VEB's proposed project financing scheme provides for a syndication of $80 / 20$, where $20 \%$ is equity, $80 \%$ is borrowed funds, syndicated through tranches to reduce the risks of project participants.

The mechanism of subsidizing rates, a qualitative selection of projects at the entrance and a qualified industry expertise implemented by VEB are also important. A new structure and competencies of the business block support the implementation of the institute's new solution - 'Project Financing Factories'. 
Table 2 Investment projects implemented in Russia with the participation of VEB

\begin{tabular}{|l|c|c|}
\hline \multicolumn{1}{|c|}{ Project name } & $\begin{array}{c}\text { Project cost, billion } \\
\text { rubles }\end{array}$ & $\begin{array}{c}\text { VEB participation } \\
\text { volume, billion rubles }\end{array}$ \\
\hline $\begin{array}{l}\text { Creation of a family of Russian regional aircraft Sukhoi Superjet 100 } \\
\text { Moscow, the City of Zhukovsky, the City of Komsomolsk-on-Amur }\end{array}$ & 150.799 & 72.982 \\
\hline $\begin{array}{l}\text { Reconstruction of the Nizhneturinskaya State District Power Station of the } \\
\text { city of Nizhnyaya Tura, Sverdlovsk region }\end{array}$ & 19.910 & 15.500 \\
\hline $\begin{array}{l}\text { Project for the development and organization of serial production of a } \\
\text { medium-range aircraft of the MS-21 family and its leasing to PJSC 'Irkut } \\
\text { Corporation' Irkutsk Region }\end{array}$ & 291.536 & 7.146 \\
\hline $\begin{array}{l}\text { Creation of aviation units' production in the Pershin Branch of OJSC NPO } \\
\text { 'Nauka', Vladimir Region }\end{array}$ & 2.228 & 1.002 \\
\hline Creation of the Express-AM7 spacecraft, Moscow & 11.738 & 7.737 \\
\hline Construction of the third phase of production of methanol 'Shchekinoazot' & 22 & 4,5 \\
\hline $\begin{array}{l}\text { Construction of an installation to produce sulfuric acid grade 'K' and an } \\
\text { improved oleum 'KuibyshevAzot' }\end{array}$ & 6,3 & 3,8 \\
\hline Development of the Udokan copper deposit & 2,9 & 0,49 \\
\hline Construction of the Amur Gas Processing Plant & 18.9 & 1.5 \\
\hline
\end{tabular}

Source: based on materials [2]

We are talking about provision of funds to borrowers within the framework of the Factory on basis of syndicated loan agreements, implemented using state support measures (subsidies and guarantees from the federal budget) and bank lending.

In 2019, an official information resource was created in VEB as part of the implementation of the 'Project Financing Factory' mechanism - a unified DataRoom system (UIS DataRoom). UIS DataRoom is a digital environment containing a single dossier of an investment project to be analyzed by participating banks and to be reflected upon by creditors regarding their position on financing the project.

In the context of interaction between the banking sector and development institutions, the activities of the VEB subsidiary, the Federal Center for Project Financing (FCPF), whose activities are related to the preparation of high-quality projects at their early stages (financial and advisory support of projects), should be especially emphasized. The FCPF singles out the World Bank Group (IFC PPP Advisory Services, IFC InfraVentures) and the European Bank for Reconstruction and Development in preparation of projects and Private Infrastructure Development Group (PIDG) as analogues in the international market.

Consequently, formation of development institutions helps to increase the level of investment in the regions and the country as a whole, encourages more efficient use of available resources, creates competitive conditions for business development, improves financial and innovative infrastructure, and also increases investment attractiveness of the territory and serves as a guarantee of sustainable social and economic development of Russia.

Development of financial system of the state is permanently associated with the expansion of lending instruments, raising funds, and increase in financial results of existing entities in the banking sector. Project financing is recognized (with an appropriate participation of the state - development institutions) among promising mechanisms for the development of modern credit organizations, the real sector of the economy, social, transport, and engineering infrastructure. This refers to a comprehensive institutional support by the state on the principles of attracting market funding and co-financing, development of legal support, providing advisory, analytical support in the development of strategic planning documents and determining spatial development priorities. [17, 18] The activity of development institutions, thereby, means promoting a new business model focused on the multilateral implementation of the interests and tasks of participants: the state, the manufacturing sector, the banking community, the insurance business, private investors, etc.

\section{REFERENCES}

[1] Stroshkov, V.P. Features of Interaction with Development Institutions in Management of Innovative Projects, Yekaterinburg: Publishing House of Ural University, 2015.- 132 p.

[2] E.E. Kharlamova, O.A. Vorotilova I.A. Ezangina, N.I. Lomakin, A.A. Polyanskaya, S.P. Sazonov, I.A. Chekhovskaya, A.I. Chunakov, Institutions for Development of Socio-Economic Systems in Digital Economy: Monograph /; scientific ed.: E.E. Kharlamova; Volgograd State Technical University, Kursk, 2019,188 p.

[3] E.V. Rodionova, A.V. Shatyrko, Russian Development Institutions: Experience, Problems, Prospects, Bulletin of the Volgograd State University. Series 3, Economics. Ecology, 2012, No. 2, pp. 109-113.

[4] Khasanov, I.F. International Experience of Creation and Functioning of Development Institutions, Transport business of Russia, 2009,No 3, pp. 37-41.

[5] Kozhevnikov, S.A. Formation of a Unified System of Development Institutions in the Region, Modern 
scientific research and innovation. - 2015. - No. 11- pp. 513-527

[6] Chashkin, V.V. New Approaches to Classification of Development Institutions, Financial analytics: problems and solutions. -2012. -No. 33.- pp. 31-38

[7] S.P. Sazonov, I.A. Ezangina, E.E. Kharlamova, M. Pridachuk, Small Innovation Businesses Attached to Higher Schools as New Funding Source of Russian Higher Education, Advances in Economics, Business and Management Research (Ser.). Vol. 38 : Proceedings of the International Conference on Trends of Technologies and Innovations in Economic and Social Studies 2017 (TTIESS 2017) (Tomsk, Russia, June 28-30, 2017 / Tomsk Polytechnic University). - [Published by Atlantis Press], 2017. - P. 168-174.

[8] E.E. Kharlamova, O.A. Kazartseva Development Institutions in the Regional Innovation Infrastructure, Scientific and Technical Reports of SPbSPU. Economic sciences. - 2015. - No. 4. - pp. 116-127.

[9].A. Kazartseva, E.E. Kharlamova, Role of Regional Development Institutions in Increasing Investment Attractiveness of the Volgograd Region, Financial analytics: problems and solutions. - 2015. - No. 40. - pp. 54-64.

[10] Bulatova E.I. Project Financing: Problems and Development Prospects in Russia, Kazan Economic Bulletin. - 2016. - No. 4 (24). - pp. 48-52.

[11] O.V. Nikulina, K.V. Baklazhkova, Specificity of Bank Project Financing of Investment Activity of Enterprises of Various Sectors of the Russian, Bulletin of the Perm University. Series: Economics. - 2016. - No. 4 (31). - pp. 164-175.

[12] Nikonova, I. A. Project Analysis and Project Financing, Moscow: Alpina Publisher, 2014.-- 154 p.

[13] Koreshkov A.A. Mechanism of Lending to Enterprises in the Real Sector of the Economy, Actual problems of modern science. - 2009. - No. 5-1. - pp. 175181.

[14] Ezangina I. A., Promising Tools for Project Financing: Modern View, Financial analytics: problems and solutions. - 2016. - No. 20. - pp. 18-32.

[15] Sazonov S. P., Ezangina I. A., Vaysbeyn K. D., Gorshkova N. V., Makarova E. A. Alternative Sources of Business Development: Mezzanine Financing, Scientific Papers of the University of Pardubice. Series D: Faculty of Economics and Administration. 2016. T. 23. № 37. C. 143-155.

[16] S.N. Silvestrov, N.V. Kuznetsov, V.P. Shestak, Project Financing of Infrastructure Monopolies in a New Model of the Russian Economy: Monograph, M.: Publishing House 'Kogito-Center', 2017. - 174 p.

[17] Milkina, I.V. Analysis of Development Institutions in the System of Supporting Innovative Activities in the Regions and Municipalities of Russia, Science. Innovation. Education. - 2016. - No. 2 (20). - pp. 61-84.

[18].A. Ezangina, N.A. Storozhilov, Strengthening the Role of Development Institutions in the Mechanism of Bank Project Financing, Finance: Theory and Practice, 2017, V.21, No. 6 (102), pp. 20-33. 